\title{
Public-private partnership in the agricultural sector: empirical estimation by factorial characteristics
}

\author{
Mikhail Kozin ${ }^{1}$, Galina Pyrchenkova ${ }^{2}$, Elena Radchenko ${ }^{1, *}$ \\ ${ }^{1}$ Federal State Research Institute of the Federal Penitentiary Service of the Russian Federation, \\ Moscow, Russian Federation, 125130, Moscow, Narvskaya str., 15 A \\ ${ }^{2}$ Academy of Management of the Ministry of Internal Affairs of Russia, Moscow, Russian Federation, \\ 125171, Moscow, Z. and A. Kosmodemyansky str., 8
}

\begin{abstract}
The course taken by the Government of the Russian Federation to modernize the economy has the goal of bringing the national economy to the path of stable growth and development. For this purpose, various regulatory acts aimed at stimulating the innovative development of the agricultural sector were adopted and are being adopted. Within these measures, a key place is given to the development of the institution of public-private partnership (hereinafter - PPP), which is an important tool for ensuring economic security of the country. We assume, that the need for PPP instruments stems from the very specifics of the agro-industrial sector, which needs the state support to function successfully. The effective development of the agro-industrial sector requires scientifically sound accounting of natural, technical, socio-historical and organizationaleconomic factors. In this regard, there is a need to identify the peculiarities of the organizational and economic mechanisms for the development of the agro-industrial sector and to work out new approaches to its formation, considering that one of these approaches is PPP.
\end{abstract}

\section{Introduction}

The development of agriculture proceeds from the goals and objectives defined by the Food Security Doctrine. According to the data of the Food and Agriculture Organization of the United Nations, 0.3 ha of arable land per capita should be a necessary condition for a stable food supply. Considering the agricultural conditions of the Russian Federation, we can note that the Russian resources of available agricultural land comprise: agricultural land 1.5 ha per capita, including arable land 0.9 ha per capita. The latest census of agricultural land showed that in Russia more than 44 million hectares were taken out of circulation, i.e. not used as arable land, pastures and hayfields. The land is overgrown with weeds, woody vegetation, swamps lose their main purpose to produce agricultural products [1]

Each country should take care of the development of the food industry in order to stimulate the development of other sectors of the economy, such as mechanical engineering, chemical industry, construction, transport. The President of the Russian

*Corresponding author: helenr2003@mail.ru 
Federation approved the new Doctrine of Food Security of Russia. The Doctrine indicates that the main direction in maintaining the national security of the country is to improve the quality of life of the country's population. The head of the state instructed the government to annually prepare reports containing an analysis, assessment and forecast of the country's food security. As follows from this program document, now the indicator "food independence" will be calculated as the ratio of the volume of domestic production to the volume of domestic consumption. At the same time, products should not only be physically and economically accessible to consumers, but also must meet the quality and safety requirements necessary for the formation of a healthy diet.

The document also highlights the interests of the state in the field of food security for the long term. Among them are the sustainable development and modernization of agriculture and fisheries, agricultural production, feed additives, the development of livestock breeding and seltction. As practice has shown, the situation with domestic production improves significantly after the corresponding sub-sectors receive subsidies soft loans and compensation for part of the capital costs. According to the doctrine, one of the priority areas for ensuring food security of the state is to increase the effectiveness of state support for producers and processors, expand their access to markets. Within the framework of the proposed measures, the development of the institution of public-private partnerships can be considered as an important tool for ensuring the country's economic prosperity in the long term. The interest of the state in the development of PPP mechanisms is preconditioned by the fact that public support of the agricultural sector provided by the other states can affect the competitiveness of domestic agricultural products on the world market.

Clarification of the concept of "public-private partnership" is extremely important for a common understanding of the content, mechanisms, tools and practical application. According to the Russian law, PPP is traditionally considered as an effective interaction between the state and business in various forms by combining their resources to achieve the common goals of socio-economic development. According to the Article 3 of the Federal Law of July 13, 2015 № 224-FL “On Public-Private Partnerships, Municipal-Private Partnerships in the Russian Federation and Amending Certain Legislative Acts of the Russian Federation" public-private partnership is "legally registered for a certain period of time and based on pooling resources, sharing risks, the cooperation of a public partner, on the one hand, and a private partner, on the other hand, which is carried out on the basis of new public-private partnership agreement." There are a number of key points that determine the nature of PPPs:

1) the parties to the PPP are a public partner and a private business;

2) the interaction of the parties is formalized and has a legal basis;

3) PPP always has a clearly defined public, socially significant focus;

4) there is a unity of goals of the parties to the public-private partnership;

5 ) in the process of implementing projects on the basis of PPP, various types of resources and contributions of the parties are consolidated;

6) financial costs and results achieved, as well as liability and risks are distributed between the parties in predetermined proportions;

7) uniform rules for the interaction of the parties are established.

Recently, there has been a slowdown in the growth rate of the global and national economies. Such factors as the investment attractiveness of the Russian agriculture, the competitiveness of the Russian products, low labor productivity, poor energy efficiency of the agricultural industry indicate the need for innovative development of the agricultural sector of the Russian economy.

The irrational use of production resources also determines the low efficiency of most business entities in the agricultural sector and even stagnation of production. Among the 
negative factors hindering the development of the agricultural sector of the Russian economy, one can also note the insufficient development of infrastructure in the industry, the lack of qualified personnel, the lack of a science-based policy to stimulate the development of human capital in rural areas, which is confirmed by the insufficient level of providing the population with affordable and high-quality domestic food in volumes and a structure consistent with sound science-based nutritional standards.

The technological lagging behind other countries can also affect the food independence of the state. One of the main documents of the strategic development planning system of the Russian Federation is the Forecast of scientific and technological development of the Russian Federation for the period until 2030, approved by the Government of the Russian Federation on January 3, 2014. It defines the most promising areas for the development of science and technology for the period up to 2030, ensuring the implementation of the country's competitive technological advantages, including the state support measures aimed at achieving the goals for the development of promising economic sectors. So, for example, given the low productivity of agricultural production and the critical lag of the research and production and technological base in the agricultural sector, the state will increase investment in the development of biotechnologies which are most in demand in agriculture and stimulate the relevant practical developments. A promising direction for the development of the research base of the agricultural sector of the economy is the development of agricultural technologies aimed at creating new highly productive, resistant to pathogens and adverse environmental conditions varieties of hybrids of agricultural plants, using biotechnologies; the use of genetic selection methods for farm animals; creation of databases containing information on the genome of breeds of farm animals for the introduction of cloning and genetic certification technologies into the breeding process.

In order to bring the Russian economy closer to the world level of development of the agricultural sector, it is necessary to introduce new technologies and modern equipment in cultivating land.

The issues of state regulation and support of agriculture, the interaction of the state and the business community in the agro-industrial sector, the development of the Russian agroindustrial complex were widely covered in the works of domestic agricultural economists, such as V.V. Nosov, M.N. Kozin, V.I. Andreev, I.Y. Surzhanskaya, E.A. Murzina, E. P. Radchenko, G.S. Pyrchenkova,V. S. Efimov, V.G. Varnavsky, A.V. Klimenko, V.A. Korolev and others. Their examination of theoretical issues in this direction is of great importance.

A significant contribution to the development and solution of public-private partnership problems in Russia was made by such domestic scientists as: V.S. Efimov, V.G. Varnavsky, A.V. Klimenko, V.A. Korolev.

The problems of promoting and developing public-private partnership projects are also being studied by foreign scientists. Among foreign researchers of this problem, we can single out M. Boult-Spearing, G. Devulf, J. Nederhand, E.H. Klijn, C. Cui,Y. Liu, A. Hope, J. Wang, Kohli, H. A., P. Basil, S. Macdonald S., C. Cheong, A. Pinz, N. Roudyani, J. Thaler, F. Geerling-Eiff, J. Potters, L. Klerkx, Zh. Do, X. Yong., G. Papadopoulos, S. Rikama, P. Alajääskö, Z. Salah-Eddine, M. Rankin, E. Nogales, P. Santacoloma, N. Mhlanga, C. Rizzo, C. Stevens, N. Kanie, F. Hartwich, E.R. Yascombe and others [2, 3, 4, $5,6,7,8,9,10,11,12,13,14,15]$.

An analysis of the generalization of the obtained results of our study revealed that in the methodological aspect there are some unresolved problems. These issues include the scientific justification for the use of public-private partnership in the agricultural sector as a mechanism for the accelerated development of the agro-industrial complex, which contributes to the increase of the level of food security in the country. 
In this study, public-private partnerships will be considered as activities aimed at achieving socially significant goals in the framework of ensuring the country's food security. For a clear coordination of activities and a more detailed consideration of a wide range of issues in this area, we suggest that subjects of public-private partnership conclude agreements on joint activities aimed at achieving and implementing social projects related to food security.

\section{Materials and Methods}

In the course of the study, the following methodology was used: a set of general scientific and special research methods (dialectical, formal logical, comparative and system analysis, indicative analysis, mathematical and statistical analysis). The analysis methods used contributed to the identification of a number of problems requiring a more in-depth study and the search for ways to solve them.

Today, the agricultural sector of Russia consists of domestic machinery and technologies that were developed in the Soviet Union. The share of modern machinery and technologies of import production is used in $1.5 \%$ of large agricultural organizations, and $0.5 \%$ of farms use imported seeds, modern technologies and innovations in the field of soil cultivation. In Russia, labor productivity in the agricultural sector is more than 4.1 times lower than in Finland and 5.2 times lower than in Canada (in the countries with agroclimatic agricultural conditions close to Russia) [5]. In particular, in grain production, the productivity index in recent years has been only 0.59 (the ratio of the productivity index in Russia is 19 centner/hectare to the average one in developed countries, which is 32 centner/hectare) [13]. These figures indicate a low level of technical and technological equipment of the domestic agricultural sector. The condition of most of the machinery is the main constraint to the technological modernization of the industry. Livestock is most poorly provided; its technical equipment does not exceed $40 \%$ of the required level [12].

The creation of legal, economic, managerial institutional foundations to accelerate the implementation of scientific and technological progress in the agricultural sector of Russia will contribute to the accelerated process of introducing innovative technologies [11]. In this regard, public-private partnerships can be considered as one of the organizational and legal mechanisms for the accelerated development of the agro-industrial sector of the economy. At the same time, there is currently no methodology for assessing the ranking of potential enterprises participating in the implementation of public-private partnership projects. A comprehensive solution to this problem can be achieved by applying the methodology for assessing the economic security of potential organizations applying for the implementation of the PPP project [7].

In our study, we will use the method of assessing the economic security of the participation of private partner organizations according to the factorial characteristics of the object. In accordance with this methodological approach, an object (region) is characterized by a certain set of factorial attributes, each of which is evaluated on a common scale of points; extreme values of the scale are interpreted as the most favorable and unfavorable for PPP processes. For example, it is necessary to estimate the profitability of projects implemented in the framework of PPP by such an indicator as net profit. We will expertly evaluate the profitability values that start with the "excellent value" (for example, over 24 $\%$ ) and the "negative value" (less than $0 \%$ ). Let us also assume that the number of possible points is taken to be 5, i.e. the favorability of the implementation of various directions of PPP by any factorial feature is evaluated by five points - from 0 to 40 , with a 10-point step.

We establish intermediate values for generating income and divide everything in three directions based on several points. Thus, based on a point estimate, the profitability of PPP projects will look as follows (the data are presented in table 1). 
Table 1. The dependence of the profitability of projects on the assessment of financial performance.

\begin{tabular}{|l|c|c|c|c|c|}
\hline $\begin{array}{c}\text { Verbal } \\
\text { estimation }\end{array}$ & $\begin{array}{c}\text { Negative } \\
\text { value }\end{array}$ & $\begin{array}{c}\text { Satisfactory } \\
\text { value }\end{array}$ & $\begin{array}{c}\text { Average } \\
\text { value }\end{array}$ & Good value & $\begin{array}{c}\text { Excellent } \\
\text { value }\end{array}$ \\
\hline Profitability, $\mathrm{R}$ & $0<=\mathrm{R}$ & $0<\mathrm{R} \leq 8$ & $8<\mathrm{R} \leq 16$ & $16<\mathrm{R} \leq 4$ & $\mathrm{R}>24$ \\
\hline Score & 0 & 10 & 20 & 30 & 40 \\
\hline
\end{tabular}

Similarly, changing only the middle row, the dependencies are built on all factorial rounds. Note that the number of groups (experiments) can be set in an arbitrary form.

An integrated assessment of the PPP results of the j-project $(\mathrm{Sj})$ for the implementation of production lines can be determined either as the sum of the estimates of factorial features (Ki):

$$
S j=\sum_{i=1}^{n} K_{i}
$$

where $\mathrm{n}$ is the number of factorial features taken into account, or as the average amount of estimates

$$
\mathrm{Sj}=\sum_{i=1} \mathrm{Ki} / \mathrm{n}
$$

If the significance of factorial features regarding the implementation of PPP directions is recognized by the researcher to be unequal, then it is necessary to introduce into the calculation the weight values of the features (Fi), reflecting their unevenness. Then the formula takes the following form:

$$
S j=\Sigma_{i=1}^{n} K i * F i / \Sigma_{i=1}^{n} F i
$$

The calculations shown have an individual form, for each project specifically, according to its individual characteristics. Therefore, a set of factors, their signs, quantitative values, problematic issues will always be different. An empirical assessment of the economic security of PPP projects has a positive side: factor values that are not quantified, investment attractiveness by region, and determination of the attractiveness level of each project can be taken into account in the calculations.

\section{Results}

The federal and regional authorities can use the results of an empirical assessment of economic security when developing and implementing PPP mechanisms in the country's agricultural sector [4].

The analysis of the empirical material allowed us to identify the importance of publicprivate partnerships for the development of the domestic agro-industrial complex and increase the level of economic and food security in Russia, to identify the problems that arise in the development of this kind of contractual relationship. Monitoring and systematization of the experience of creating PPPs in different countries of the world showed that the mechanism of their use in the interests of the state is different in each country, has distinct national features and legal forms. Each PPP project has individual characteristics. Therefore, projects can vary in structure, composition of participants, directions that are formed within the framework of the PPP model [9]. In this regard, a clear definition of the priority interests of government agencies involved in the organization and implementation of PPP projects is necessary. 
As part of the study of the problems of the role of PPP in ensuring the economic security of the state, questionnaire was developed and a survey of participants in PPP projects in the Russian Federation was conducted [10]. The application of an innovative approach in the agricultural sector is the most appropriate solution for the rapid and highquality development of the country's agricultural sector. The use of labor-intensive and materially expensive farming methods should be replaced by energy-saving and laborsaving technologies. This applies especially to livestock breeding, since most of the breeding of animals is concentrated in private farms, the cost of production subsequently produced is quite high.

The share of the agro-industrial complex in the USA is more than $50 \%$, while in Russia this indicator tends to $6 \%$. In European countries, the output of high-tech products is more than $20 \%$, while in Russia this figure is no more than $0.3 \%$. Thus, the implementation of public-private partnership instruments in the agricultural sector of Russia can be considered as joint cooperation between the state and business for the introduction of innovative developments in the agricultural sector [11].

The most common form of public-private partnerships are national projects and targeted programs. The joint activity between the state and business in the field of applying PPP mechanisms is as follows: the state, with the help of research institutes, develops publicprivate programs, works out a methodology and mechanism for implementing such programs, and the business community invests into these projects. The formation of agroindustrial holdings by means of combining small forms of farms will contribute to a positive socio-economic result, and the country's agriculture can work effectively according to the program-targeted management method. This effect may include:

1. Increase in meat production.

2. Increase in the number of livestock - by 30 thousand heads;

3. Formation of the best practices and creation of new PPP projects.

4. Creation of new jobs and the introduction of new specialties.

5. Introduction of high-tech equipment in the agricultural sector.

6. Formation of the agricultural complex with a full cycle (construction, production, livestock breeding, feed mills, processing, maintenance, implementation).

7. Improving product quality and increasing capacity through innovation and attracting investment.

8. Formation of continuous growth in agricultural development.

9. Careful attitude to the environment through innovative equipment and even distribution of livestock complexes throughout Russia.

\section{Discussion}

To achieve these goals, it is necessary to solve the following tasks:

to carry out a selection of the most necessary goods for the needs of the population, to determine their volume and form a stock;

- to form agricultural holdings by building new ones and reconstructing old and abandoned collective farms;

- to use secondary resources obtained in the production process;

- to introduce innovative technologies in the production process and the solution of environmental problems;

- to increase the output of the product range by creating a complete closed cycle of the production process.

The Food Security Doctrine of the Russian Federation for 2013-2020 outlines the directions of the development of agriculture and the regulation of agricultural markets in order to ensure food independence of the country. 
This program is designed to stimulate the increase in the efficiency of the Russian agroindustrial complex and the competitiveness of Russian agricultural products in the domestic and foreign markets through the innovative development of the agro-industrial complex, creating an enabling environment for the development of entrepreneurship, and increasing the investment attractiveness of the industry.

The Program includes measures that provide food chains for each type of crop and livestock products (production - processing - logistics - market). At the same time, food security in Russia is supposed to be ensured by building up competitive products and selfproduced food products through comprehensive modernization.

The target Program provides for co-financing by the state and business of certain measures for the development of agricultural sectors, through which it will be possible to increase production in accordance with the parameters of food security and to provide the sustainable development of territories.

\section{Conclusions}

When implementing public-private partnership projects in the agricultural sector, we may encounter the following difficulties:

- problems in setting priorities by both, the state and the business;

- uneven funding of various PPP projects by the state;

- the complexity and insufficient study of the legal framework of PPP projects, which can lead to unplanned and undesirable consequences.

The benefits of public-private partnership projects include:

- avoiding intermediaries of procurement procedures, leading to savings of time and budgetary funds, stabilization of volume in production;

- quality control and safety of manufactured products that have a positive impact;

- reducing the cost of the final product due to the competent organization of production and cost reduction;

- expanding the range and volume of products;

It seems promising to create, under PPP projects, a production with a closed full production cycle:

- meat processing and production of semi-finished meat products;

- production of vegetables (potatoes, beets, carrots, cabbage, etc.) on agricultural lands available in the region;

- production and processing of grain crops, production of flour, cereals, bakery products, vegetable oil, provided that the necessary agricultural machinery and equipment are supplied.

There are several main reasons for motivating the state to participate in PPPs:

1. The desire to attract private capital in solving global, strategic and socially significant tasks, thus increasing the funding of these projects;

2. The desire to significantly increase the efficiency of government costs for the management of these projects due to the efforts and capabilities of private business partners.

Thus, in the Russian practice over the past 10-15 years, a certain pattern of relations between the state and business has been developed. The modern "partnership" in the framework of PPP is built on the basis of mutually beneficial cooperation between public and private structures, created for specific purposes and based on relevant agreements of the parties. It is obvious that the PPP mechanism at the moment is an extremely relevant area for research.

Thus, the proposed methodological approach using financial and economic indicators to determine the safety of potential organizations involved in the implementation of PPP 
projects allows to obtain as much as possible a generalized assessment of the state's economic security, taking into account the adopted restrictions on the implementation of promising PPP projects.

\section{References}

1. Food and Agriculture Organization of the United Nations, http://www.fao.org/statistics/ru/

2. M. Bult-Spiering, G. Dewulf, Strategic Issues in Public-Private Partnerships: an International Perspective (Blackwell Publishing Ltd., UK, 2016)

3. J. Nederhand, E.H. Klijn, Stakeholder Involvement in Public-Private Partnerships: Its Influence on the Innovative Character of Projects and on Project Performance (Adm. Soc., 2016)

4. C. Cui, Y. Liu, A. Hope, J. Wang, International Journal of Project Management 36(5), 773-794 (2018) doi.org/10.1016/j.ijproman.2018.03.004

5. H.A. Kohli, P. Basil, Journal of Emerging Market Economies 3(1), 59-110 (2010)

6. S. Macdonald, C. Cheong, The Role of Public-Private Partnerships and the Third Sector in Conserving Heritage Buildings, Sites, and Historic Urban Areas (The Getty Conservation Institute, Los Angeles, USA, 2014)

7. A. Pinz, N. Roudyani, J. Thaler, Public Manag. Rev. 20, 1-22 (2017)

8. F. Geerling-Eiff, J. Potters, L. Klerkx, NJAS - Wageningen Journal of Life Sciences 88, 76-95 (2019) https://doi.org/10.1016/j.njas.2018.10.001

9. Zh. Do, J. Wang, X. Yong, Comparative study of China and USA public private partnerships in public transportation, // https://www.researchgate.net

10. G. Papadopoulos, S. Rikama, P. Alajääskö, Z. Salah-Eddine, Statistics on small and medium-size enterprises (2018) https://ec.europa.eu/eurostat/statisticsexplained/index.php/Statistics_on_small_and_medium-sized_enterprises

11. M. Rankin, E. Nogales, P. Santacoloma, N. Mhlanga, C. Rizzo, Recommended citation FAO. Public-private partnerships for agribusiness development $-A$ review of international experiences (Rome, Italy, 2016)

12. C. Stevens, N. Kanie, Int Environ Agreements 16, 393-396 (2016) https://doi.org/10.1007/s10784-016-9324-y

13. L. Demmou, A. Wörgötter, OECD Economics Department Working Papers 1189 (2015) http://dx.doi.org/10.1787/5js4w26114r2-en.

14. F. Hartwich, Building and Strengthening Public-Private Partnerships in Agricultural Research. Agricultural Innovation Systems: An Investment Sourcebook (2012) http://www. siteresources.worldbank.org./INTARD/Resources/3358071330620492317/9780821386842.pdf

15. E.R. Yescombe, Public-Private Partnerships: Principles of Policy and Finance (Linacre House, Oxford, 2011) 